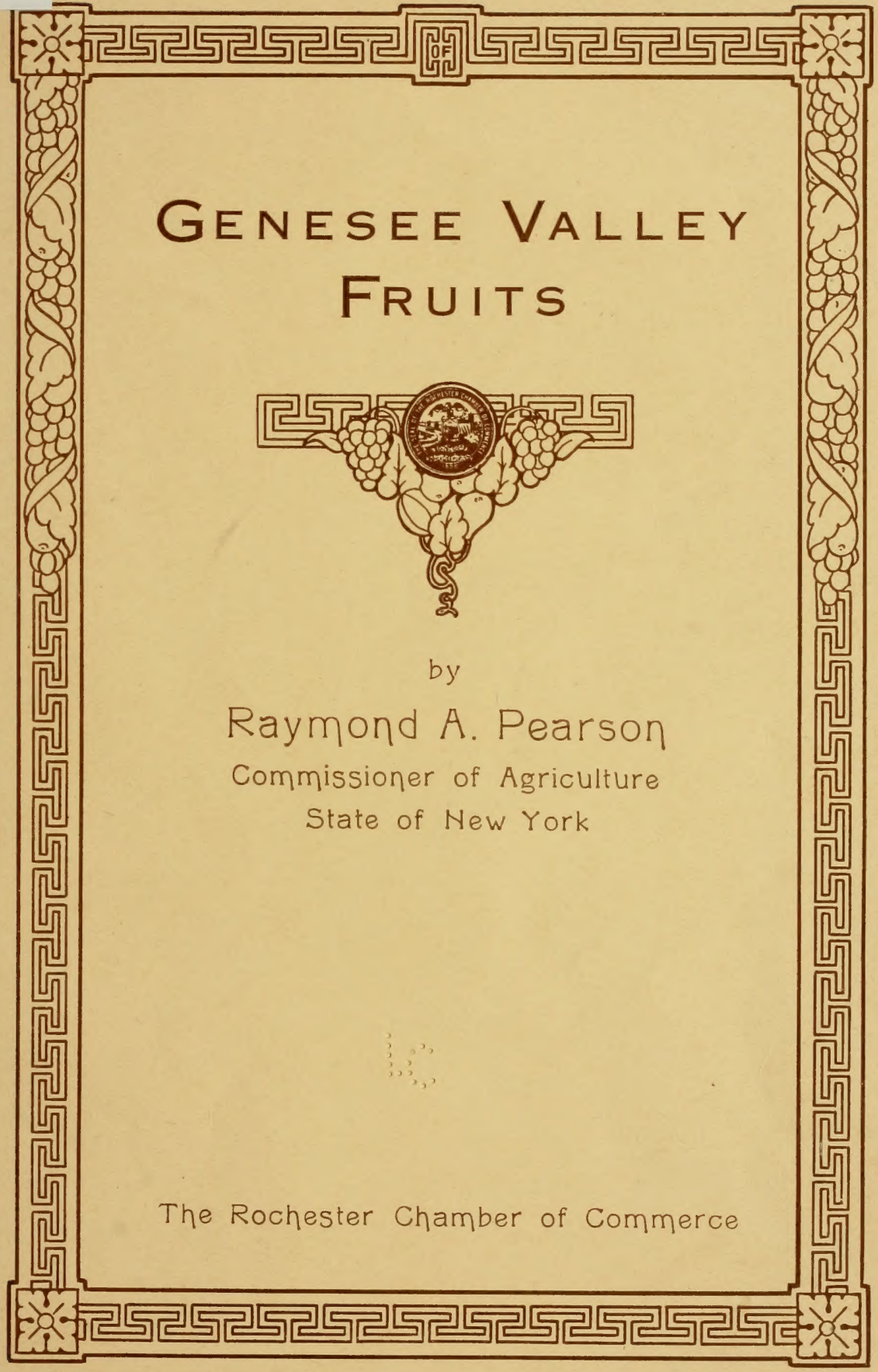





\section{GENESEE VALLEY FRUITS}

An Address delivered at the November Corporation Dinner of the Rochester Chamber of Commerce by Hon. Raymond Al Pearson, Commissioner of Agriculture of the State of New York

November 20th. 1911

\section{Publisḩed by}

The Rochester Chamber of Commerce Rochester, N. Y. 
Lack of Agricultural Knowledge

\section{Development of the West}

\section{Stealing} Fertility

50

Million

Loss of

Fertilization
$\mathrm{I}^{\mathrm{T}}$

is stated that the Rochester Chamber of Commerce is interested in the dissemination of information regarding the products of this Genesee Fruits Country. This is a worthy purpose for any organization. There is need for exploiting many features of agriculture in New York State. The ignorance existing among our people along this line is amazing. It seems that many otherwise well informed persons are twenty years behind the times in general information regarding agriculture. This should not seem so strange, however, when we know that many people are behind the times in their knowledge of most important affairs, even including those most discussed in our newspapers.

d It is harmful to our fruit-growing and general agricultural interests of today, to be judged by the conditions of the past. During a period of about twenty years, which ended only a few years ago, we were in bad shape from an agricultural standpoint throughout the entire east. This was due to the rapid development of the west. That development was a wonderful thing for the country and was supported chiefly by the farmers of the east. The support was magnificent, whether given intentionally or not, but, it practically undermined successful farming of all kinds in the east and for an extended period there was great depression. For a time, farm products had to be sold for less than cost, and, it was only that eastern farmers could draw on their reserve of soil fertility, transforming it into ready cash, that enabled them to stay in business.

I In 1895, corn sold as low as $25 \mathrm{C}$ a bushel and each bushel carried away from the farm, $17 \mathrm{C}$ worth of plant food. In 1894 , wheat sold at $523 / 4 \mathrm{c}$ a bushel and each bushel carried $23 \mathrm{C}$ worth of plant food. In 1896 , oats dropped to $161 / 2 \mathrm{C}$ a bushel with each bushel carrying $10 \mathrm{I} / 2 \mathrm{c}$ worth of plant food. At the same tine timothy hay sold at $\$ 8.00$ a ton with each ton carrying over $\$ 5.00$ wroth of plant food. Eastern farmers lived by stealing fertility from their lands.

I Although the situation is not so serious now, yet the removal of fertility continues, and it is a problem that will need our serious attention in the future.

II It has been estimated that the value of plant food lost annually from our lands through consumption and sewage is not less than fifty million dollars in New York State. 


\section{RISE IN MONROE COUNTY VALUES}

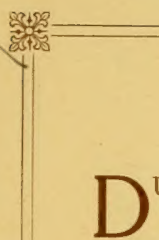

URING the period of depression, Monroe County suffered with others. The value of her farm property during the decade from 1870 to 1880 fell from forty-three to thirty-eight and seven-tenths millions of dollars. During the next decade it fell in value another million; at the same time. the State lost eighty-eight millions in value of farm property. From 1890 to 1900 , the value in Monroe County increased two and one-half millions, while in the State, it gained one hundred and one millions. From I90o to I9I0, the value of farm property in Monroe County jumped from forty to practically sixty millions of dollars, an increase of $49.3 \%$; at the same time the value of farm property in the State increased from a little over one billion to nearly one and one - half billions of dollars, the increase being at the rate of $35.7 \%$. During this decade of remarkable increases, the farm land values in Monroe County increased $42 \%$; farm building values $52 \%$; farm implement and machinery values $71 \%$; farm animals, $74 \%$.

I Today, agriculture is receiving more attention than ever, within the agriculture field itself, from the public generally and especially from the commercial bodies, such as the Rochester Chamber of Commerce. This is due to three things:

FIRST - because of better prices for agricultural products. This stimulates producers and leads to increasing values of farm property.

SECOND - because of the belief among consumers that the increased cost or living is due to the increased cost of farm products. It would be interesting to show what a small part of the consumers' money finds its way to the producer and how little a slight increase in price to the producer actually affects the cost of living; yet we do admit that increased prices received by farmers affect the cost of living.

THIRD - Agriculture is receiving attention from commercial men because of their interest in the general welfare, and because they appreciate that by helping agriculture they are helping themselves.

व Aside from all other considerations, note what it would mean to business to have a slight increase in agriculture production.

II An increase of only one bushel of grain per acre on all improved agricultural land in the United States would require I 2,500 extra trains of 50 cars each for transportation. One can well imagine what this would mean as an incentive to business, the stimulus being directed along the line from one industry to another until it covered the entire country and affected practically every person.

\section{Decrease and Increase of Values}

Cost of Living

12,500

Extra Trains of Fifty

Cars Each

Needed for Increase of one Bushel per Acre 


\section{STANDING OF MONROE COUNTY}

Largest

Producer of

Apples

First

Place in

Wheat

Production
7 HESE are reasons that justify us in promoting our agriculture. Then let us consider how best to proceed. Suppose we assume that we own Monroe County and all that is in it. What should we do to increase its agriculture? The business man would say to take an inventory before we do anything else. And here we find a startling array of facts and figures.

I According to the latest complete census figures published, Monroe County stands, among other New York Counties:

First in production of apples and nursery stock.

Second in total production of potatoes.

Second in total value of farm products.

Second in total value of farm property.

Third in orchard fruits.

Third in dried beans.

Third in miscellaneous vegetables.

Fourth in small fruit.

and when compared with other counties on basis of production per square mile, Monroe County is :

First in nursery products.

Third in orchard fruits.

Third in potatoes.

Fourth in total value of products.

Fifth in oats, small fruit and dry beans.

(I Director of Census, E. Dana Durand, has courteously furnished a preliminary report of production of Monroe County as recorded in the last census taken in 1910 , and it is shown that this county has risen in ten years from

Fourth to third in number of horses on farms

Eleventh to fourth in number of swine.

Fifteenth to tenth in total value of domestic animals.

Seventh to third in total corn production.

Seventh to third in oat production.

Held first place in wheat production.

Risen from fifteenth to sixth in rye production.

Held third place in production of beans.

II Similar statements of wonderful development could be made for the neighboring counties. 
RE these things known right here at home, or has our light been hid under a bushel? Who knows of our great possessions and our greater possibilities? We have all heard of the wonderful Hood River Valley of Oregon. The whole world has heard of it. And who has not heard of the famous Wenatchee Valley in Washington? But these are small and unimportant places when compared with the great fruit districts in this vicinity. President W. C. Brown tells us that five stations on the New York Central Railroad, not far from here, recently shipped more apples in one year than were shipped, not from the two valleys named, but from the entire states of Oregon and Washington combined. Does the world know this? Is it known here at home? How many know that Monroe County ranks first in apple production of all counties in the state; yes, first of all the counties in the United States. Niagara, Wayne, and Orleans rank second, third and fourth of all the counties in the United States according to the last available census figures.

a] When the quality of fruit is considered, we have no fear of competition from the west, for it is recognized there as well as here that eastern apples are superior.

I Having taken the inventory as business men in possession of this great country, naturally our next step would be to advertise our product. This may be done in many ways, some more costly than others. The identity of your splendid fruit should be preserved so that you may receive the credit that is due you wherever it is sent. Instead of letting your fruit be absorbed into the world's great markets unlabeled or unknown or marked by so many different names that no one can remember them, why not have one trademark for the whole Genesee Fruits Country, which will be used only on the best? Let a responsible organization stand behind this and protect it, so that it will become as well known as "Rochester Made Means Quality."

I As business men, owning this county, we would give attention to the development of its resources, which would serve the same purpose as increasing its size. Formerly, a people desiring to increase their possessions, would go out and conquer their neighbors and add to their area. Now, we go out and conquer ignorance and add to our productivity. It is reasonable to say that the value of our agricultural products in this 


\section{AGRICULTURAL EXPERIMENT STATIONS}

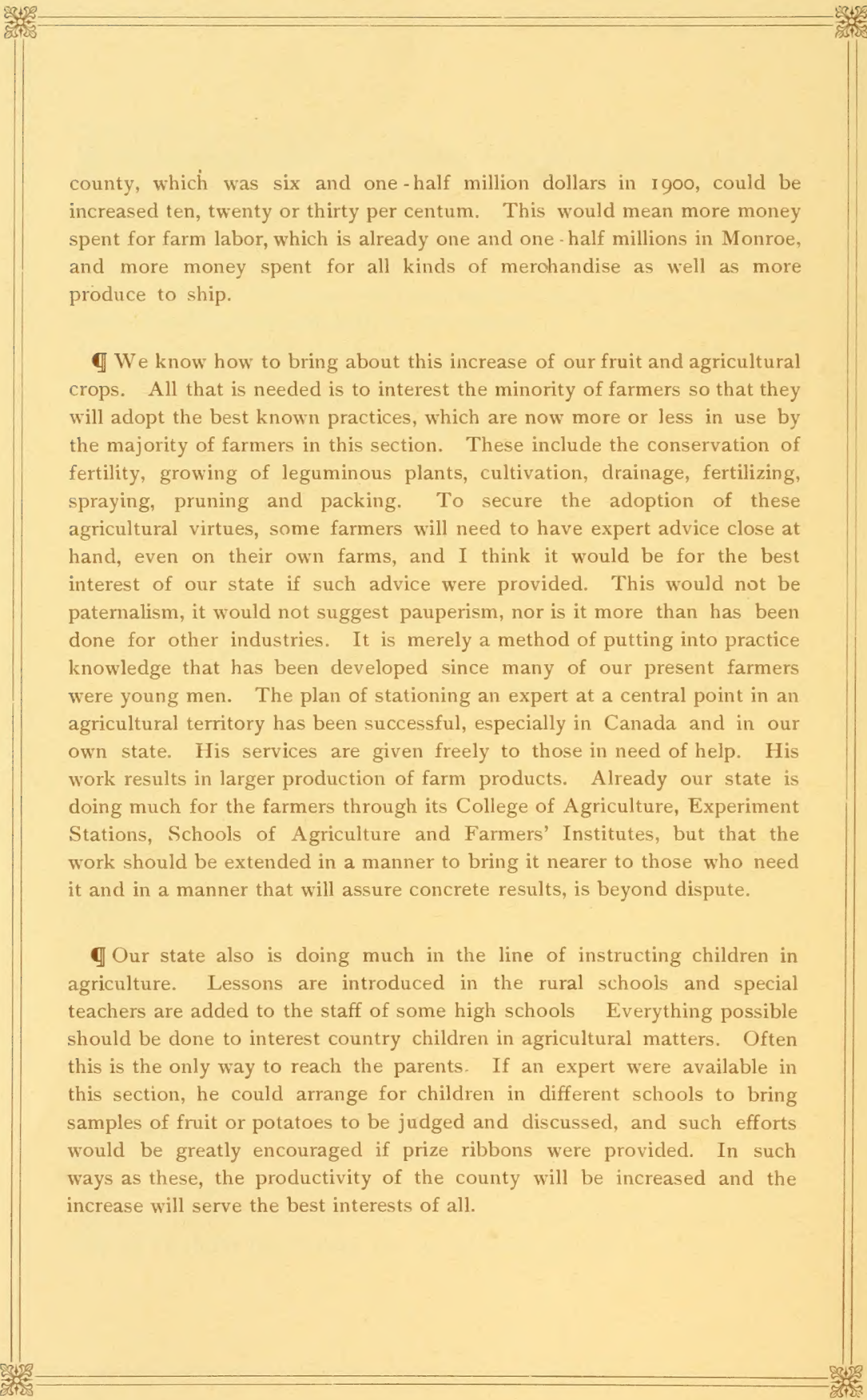

Farming

Experts

Teach

the

Children

county, which was six and one-half million dollars in I9oo, could be increased ten, twenty or thirty per centum. This would mean more money spent for farm labor, which is already one and one - half millions in Monroe and more money spent for all kinds of merohandise as well as more produce to ship.

9 We know how to bring about this increase of our fruit and agricultural crops. All that is needed is to interest the minority of farmers so that they will adopt the best known practices, which are now more or less in use by the majority of farmers in this section. These include the conservation of fertility, growing of leguminous plants, cultivation, drainage, fertilizing, spraying, pruning and packing. To secure the adoption of these agricultural virtues, some farmers will need to have expert advice close at hand, even on their own farms, and I think it would be for the best interest of our state if such advice were provided. This would not be paternalism, it would not suggest pauperism, nor is it more than has been done for other industries. It is merely a method of putting into practice knowledge that has been developed since many of our present farmers were young men. The plan of stationing an expert at a central point in an agricultural territory has been successful, especially in Canada and in our own state. His services are given freely to those in need of help. His work results in larger production of farm products. Already our state is doing much for the farmers through its College of Agriculture, Experiment Stations, Schools of Agriculture and Farmers' Institutes, but that the work should be extended in a manner to bring it nearer to those who need it and in a manner that will assure concrete results, is beyond dispute.

(I) Our state also is doing much in the line of instructing children in agriculture. Lessons are introduced in the rural schools and special teachers are added to the staff of some high schools Everything possible should be done to interest country children in agricultural matters. Often this is the only way to reach the parents. If an expert were available in this section, he could arrange for children in different schools to bring samples of fruit or potatoes to be judged and discussed, and such efforts would be greatly encouraged if prize ribbons were provided. In such ways as these, the productivity of the county will be increased and the increase will serve the best interests of all 


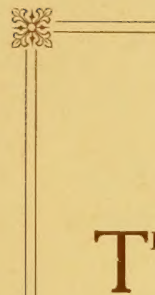

HE business men of Rochester are noted for their clean methods, their enterprise and the successful outcome of whatever they set out to accomplish. They are entitled to great credit for the attractiveness of this city, a place traveling men and strangers like to visit, because they are so well cared for and because they find all surroundings so pleasant. And now it appears that these business men, in a determined way, will co-operate with the farming interests for mutual benefit. It would be difficult to prophesy what will be the outcome of such co-operation. I consider the business interests of the city fortunate in having at hand such a splendid field for operations, and I consider the agricultural interests in this vicinity fortunate in being able to command the attention of such a well organized and able body of business men. In closing, I would personify the Genesee Fruits Country and address a toast to her :

I] I congratulate you Genesee Fruits Country. I salute you. Your superior is not known. These many years you have poured forth your bounty. We have grown up in your midst and have not appreciated your vast importance. But, as children love their benefactor, so we have loved you. Now, as never before, we realize your wonderful beauty and worth and power. We pledge you our best care and will sing your praises always. 
A

Special

Message

to the

Grower

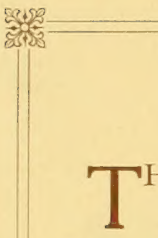

THE Rochester Chamber of Commerce is interested in increasing the productivity of the soil of this section of New York State, because:

Rochester must feed its increasing industrial population.

Rochester is the logical center of interest and activity of this fertile section.

Therefore, the Chamber of Commerce is willing to spend time and money to accomplish the following ends :-

To make a survey of the products of this section and to classify the information.

To give information about the value and scope of the agricultural development of this section.

To aid growers in their efforts toward co-operation and solidarity.

To stimulate them to take the fullest advantage and the opportunities for marketing their products by improved methods of sorting, packing, labelling and advertising.

To make known to the United States the vast food supplies within this section, thereby increasing sales and stimulating the most efficient methods of growing.

These things can be accomplished only by your co-operation and cordial support-

Which means that every reader of this book who is a grower should send his name and address to the Chamber, together with a list of his products, and any facts in connection therewith. From this a mailing list will be made up.

Organizations throughout this section now working to the ends mentioned should supply us with their membership list, advise their special objects and keep in touch with the work of the Chamber.

These things mean dollars to you. Do not set this aside for future action. Do it now. 

